PROPERTY, POWER, AND AUTHORITY IN RUS AND

LATIN EUROPE, CA. I000- I 236 


\section{BEYOND MEDIEVAL EUROPE}

Beyond Medieval Europe publishes monographs and edited volumes that evoke medieval Europe's geographic, cultural, and religious diversity, while highlighting the interconnectivity of the entire region, understood in the broadest sense-from Dublin to Constantinople, Novgorod to Toledo. The individuals who inhabited this expansive territory built cities, cultures, kingdoms, and religions that impacted their locality and the world around them in manifold ways. The series is particularly keen to include studies on traditionally underrepresented subjects in Anglophone scholarship (such as medieval eastern Europe) and to consider submissions from scholars not natively writing in English in an effort to increase the diversity of Anglophone publishing on the greater medieval European world.

\section{Series Editor}

Christian Alexander Raffensperger, Wittenberg University, Ohio

\section{Editorial Board}

Kurt Villads Jensen, Stockholms Universitet Balázs Nagy, Central European University, Budapest Leonora Neville, University of Wisconsin, Madison

\section{Acquisitions Editor}

Erin T. Dailey 


\section{PROPERTY, POWER, AND AUTHORITY IN RUS AND LATIN EUROPE, CA. 1000-I 236}

YULIA MIKHAILOVA

ARChumanities press 


\section{British Library Cataloguing in Publication Data}

A catalogue record for this book is available from the British Library

\section{(C) 2018, Arc Humanities Press, Leeds}

This work is licensed under a Creative Commons Attribution-

NonCommercial-NoDerivatives 4.0 International Licence.

The authors assert their moral right to be identified as the authors of their part of this work.

Permission to use brief excerpts from this work in scholarly and educational works is hereby granted provided that the source is acknowledged. Any use of material in this work that is an exception or limitation covered by Article 5 of the European Union's Copyright Directive (2001/29/EC) or would be determined to be "fair use" under Section 107 of the U.S. Copyright Act September 2010 Page 2 or that satisfies the conditions specified in Section 108 of the U.S. Copyright Act (17 USC $\S 108$, as revised by P.L. 94-553) does not require the Publisher's permission.

ISBN: 9781942401483

e-ISBN: 9781942401490

https://arc-humanities.org

Printed and bound by CPI Group (UK) Ltd, Croydon, CR0 4YY 